\title{
HUBUNGAN ASUPAN PROTEIN, ZAT BESI, DAN SENG DENGAN KEJADIAN INFEKSI KECACINGAN PADA BALITA DI KOTA SEMARANG
}

\author{
Talitha Ulayya $^{1}$, Aryu Candra ${ }^{1}$, Deny Yudi Fitranti ${ }^{1}$ \\ ${ }^{1}$ Departemen Ilmu Gizi, Fakultas Kedokteran, Universitas Diponegoro \\ Jln. Prof. H. Soedarto, SH., Semarang, Telp (024) 76402881, Email : gizifk@undip.ac.id
}

\begin{abstract}
Background: Protein, iron and zinc are antibody-forming ingridients that affect the child's immune system against infection. The incidence of helminth infection in toddler in Indonesia was around $21 \%$. The purpose of this study was to analyze the correlation between protein, iron and zinc intake with the incidence of helminth infection in toddler.

Methods : This study is cross sectional with toddlers aged 2-5 years $(n=50)$, taken by purposive sampling technique. Data collected include history protein intake, intake of iron and zinc intake were taken using the Semi-Quantitative Food Frequency Questionnaire (SQFFQ). Data on personal hygiene and environmental sanitation by filling out questionnaires. Data on the incidence of helminthiasis infection was obtained by filling out symptom sign questionnaires and laboratory tests using the kato-katz method. Data were analyzed using Fisher's Exact Test

Results : There was one subject infected with Enterobius vermicularis. Based on symptoms, as many as 6\% of subjects were found to be positive for helminthiasis infection. Based on the sign, $2 \%$ of the subjects were found to be positive for helminthiasis infection. Interview results showed that $46 \%$ of subjects had poor personal hygiene, and $62 \%$ of subjects had poor environmental sanitation. Intake of protein, iron, and zinc is not a factor that affects helminthiasis infection Conclusion: There is no correlation between protein, iron, and zinc iintake with the incidence of helminth infection in toddler.
\end{abstract}

Keyword : Helminth infection, Protein, Iron, Zinc

\begin{abstract}
ABSTRAK
Latar Belakang : Protein, zat besi dan seng adalah pembentuk antibodi yang berpengaruh pada sistem imunitas anak terhadap serangan infeksi. Kejadian infeksi kecacingan pada balita di Indonesia Tahun 2006 sekitar 21\%. Penelitian ini bertujuan untuk menganalisis hubungan asupan protein, zat besi, dan seng dengan kejadian infeksi kecacingan pada balita.

Metode : Jenis penelitian ini adalah cross sectional dengan subjek balita berusia 2-5 tahun ( $n=50)$, diambil dengan teknik purposive sampling. Data yang dikumpulkan meliputi riwayat asupan protein,zat besi,dan seng diambil menggunakan Semi Quantitative Food Frequency Questionnaire (SQFFQ). Data personal hygiene dan sanitasi lingkungan dikumpukan dengan pengisian kuesioner. Data kejadian infeksi kecacingan diperoleh dengan pengisian kuesioner tanda gejala dan uji laboratorium dengan metode kato-katz. Data dianalisis menggunakan Uji Fisher's Exact. Hasil : Terdapat satu subjek terinfeksi cacing Enterobius vermicularis. Berdasarkan gejala,sebanyak 6\% subjek diketahui positif infeksi kecacingan. Berdasarkan tanda, 2\% subjek diketahui positif infeksi kecacingan. Hasil wawancara menunjukkan bahwa 46\% subjek memiliki personal hygiene tidak baik, dan 62\% subjek memiliki sanitasi lingkungan tidak baik. Asupan protein, zat besi, dan seng tidak menjadi faktor yang mempengaruhi infeksi kecacingan.
\end{abstract}

Simpulan : Tidak ditemukan hubungan antara asupan protein,zat besi,dan seng dengan kejadian infeksi kecacingan pada balita.

Kata Kunci : Infeksi Kecacimgan, Protein, Zat Besi, Seng

\section{PENDAHULUAN}

Usia balita merupakan masa di mana proses pertumbuhan dan perkembangan terjadi sangat pesat, namun pada kelompok ini merupakan kelompok yang rentan mengalami masalah gizi. Masalah gizi kurang dapat menyebabkan penurunan kemampuan kognitif dan risiko kematian yang meningkat. ${ }^{1}$ Di Indonesia data yang didapatkan berdasarkan Riskesdas pada Tahun 2013 didapatkan hasil prevalensi berat badan kurang secara nasional. Prevalensi balita dengan berat kurang pada Tahun 2013 adalah 19,6\%, terdiri dari $5,7 \%$ gizi buruk dan $13,9 \%$ gizi kurang. ${ }^{2}$
Masalah gizi kurang pada balita umumnya disebabkan oleh beberapa faktor yaitu penyebab langsung dan penyebab tidak langsung. Penyebab langsung yaitu makanan anak dan penyakit infeksi yang mungkin diderita anak. Penyebab tidak langsung yaitu ketahanan pangan, pola pengasuhan anak, serta pelayanan kesehatan. ${ }^{3}$ Infeksi cacing adalah salah satu penyakit infeksi yang sering terjadi di Negara berkembang, salah satunya adalah Indonesia. Cacing usus golongan STH (Soil Transmitted Helminth) yang masih menjadi persoalan kesehatan masyarakat di Indonesia yaitu diantaranya 
cacing gelang (Ascaris lumbricoides), cacing cambuk (Trichuris trichiura) dan cacing tambang (Necator americanus atau Ancylostoma duodenale). Cacing usus golongan non STH (non-Soil Transmitted Helminth) yang dapat menimbulkan masalah bagi kesehatan, diantaranya cacing kremi (Enterobius vermicularis) dan cacing otot (Trichinella spiralis). ${ }^{4}$ Infeksi cacing dapat menyebabkan terhambatnya pertumbuhan fisik dan gangguan kognitif , khususnya pada anak. ${ }^{5}$ Anak dengan infeksi cacing ini akan mengalami malabsorpsi, inflamasi, dan penurunan asupan makan karena nafsu makan yang kurang saat infeksi. $^{6}$

Data dari World Health Organization (WHO) pada Tahun 2016, lebih dari 1,5 milyar orang atau sekitar 24\% penduduk dunia terinfeksi cacing. Angka kejadian terbesar berada di sub-Sahara Afrika, Amerika, China dan Asia Timur. Departemen Kesehatan Republik Indonesia menyebutkan pada Tahun 2006 sekitar 21\% kejadian infeksi kecacingan menyerang anak usia prasekolah dan sekolah. ${ }^{7}$ Secara teoritis kejadian kecacingan dipengaruhi oleh faktor sanitasi lingkungan dan higiene personal yakni: kebiasaan mencuci tangan, frekuensi potong kuku anak, kebiasaan bermain di tanah, kepemilikan jamban, lantai rumah dan ketersediaan air bersih. ${ }^{7}$ Penularan infeksi kecacingan dapat terjadi melalui beberapa jalan, salah satunya yaitu telur infektif masuk ke mulut bersama makanan dan minuman yang tercemar melalui tangan yang kotor terutama pada anak. ${ }^{8,9}$

Asupan zat gizi baik zat gizi makro maupun zat gizi mikro berpengaruh terhadap sistem imun anak balita. Salah satu contoh zat gizi makro yang berpengaruh terhadap sistem imun adalah protein. Protein adalah pembentuk antibodi yang berpengaruh pada sistem pertahanan anak terhadap serangan infeksi. ${ }^{10,11}$ Protein dibutuhkan untuk formasi antibodi seperti immunoglobulin dan sel T. Zat gizi mikro terdiri dari vitamin dan mineral juga sangat berguna untuk berbagai fungsi dalam tubuh. Defisiensi salah satu zat gizi mikro akan terkait dengan defisiensi zat gizi mikro lainnya, seperti pada defisiensi seng, akan terkait dengan defisiensi zat besi. ${ }^{12}$ Seng berperan untuk menjaga supaya sel imun tidak spesifik seperti neutrofil, monosit, makrofag, sel natural killer, serta sel imun spesifik seperti sel limfosit $\mathrm{T}$ dan $\mathrm{B}$ bisa berfungsi normal. ${ }^{13}$ Zat besi juga mempunyai peranan penting dalam sistem imunitas, proliferasi dan aktifasi dari sel T, sel B dan sel natural killer. $^{14}$ Penelitian menunjukkan defisiensi besi akan menyebabkan penurunan fungsi system imunitas melalui penurunan fungsi thymus, proliferasi sel T dan proliferasi thymosit. Seng dan besi merupakan bahan pembentuk sel $\mathrm{T}$ dan sel $\mathrm{B}$. Masuknya cacing ke dalam tubuh akan memicu terbentuknya sel Th2 dari sel T. Setelah terbentuk, sel Th2 merangsang sel B untuk berdeferensiasi menjadi sel plasma yang akan menghasilkan dan mensekresikan IgE. IgE adalah sistem imun yang berperan dalam merespon infeksi parasit. ${ }^{15}$

Rata-rata konsumsi per kapita per hari penduduk Provinsi Jawa Tengah adalah 51,3 gram untuk protein, atau defisit protein $65,9 \% .{ }^{16}$ Penelitian Tahun 2010 menyebutkan anak dengan persentase defisiensi zat besi $(\mathrm{Fe})$ yaitu sebesar $50 \%$ dan defisiensi seng $(\mathrm{Zn})$ sebesar $17 \% .{ }^{17}$ Dilihat dari tingkat konsumsi diketahui bahwa sebesar 79,1\% anak dengan konsumsi zat besi yang kurang dan 94,5\% anak dengan konsumsi seng yang kurang di Kota Semarang. ${ }^{18,19}$ Penelitian mengenai asupan seng dan zat besi pada balita pernah dilakukan di kelurahan Jomblang, Semarang. Hasil penelitian menunjukkan bahwa, terdapat $26,2 \%$ responden yang kekurangan asupan seng. Selain itu, terdapat $58,5 \%$ responden yang kekurangan asupan zat besi. ${ }^{20}$ Berdasarkan uraian latar belakang tersebut, maka penulis tertarik meneliti tentang hubungan asupan protein, zat besi, dan seng dengan kejadian infeksi kecacingan pada balita di Kota Semarang.

\section{METODE}

Penelitian ini dilakukan pada bulan Juli tahun 2017-Agustus tahun 2018 di Kelurahan Jomblang, Kecamatan Candisari, Kota Semarang dan termasuk dalam lingkup bidang gizi masyarakat. Penelitian dilakukan dengan dasar Ethical Clearane (EC) No.394/EC/FK-RSDK/V/2018 yang dikeluarkan oleh Fakultas Kedokteran, Universitas Diponegoro. Desain yang digunakan dalam penelitian ini adalah cross sectional untuk melihat hubungan asupan protein,zat besi,dan seng dengsn kejadian infeksi kecacingan pada balita.

Populasi terjangkau penelitian adalah balita usia 2-5 tahun di Kelurahan Jomblang, Kecamatan Candisari, Kota Semarang. Perhitungan besar sampel menggunakan rumus proporsi satu populasi, didapatkan jumlah sampel minimal yang dibutuhkan sebanyak 34 orang, dan ditambah dengan kemungkinan drop out sebanyak $10 \%$ sehingga menjadi 38 orang. Metode pengambilan sampel menggunakan metode purposive sampling. Subjek diperoleh sebanyak 50 balita berdasarkan hasil skrinning yang memenuhi kriteria inklusi. Kriteria inklusi adalah balita berusia 2-5 tahun, orang tua atau wali balita bersedia mengikuti penelitian, dan balita tidak menderita penyakit kronis seperti HIV, kanker,dan TB. Kriteria eksklusi adalah orangtua atau wali balita tidak mengembalikan pot feses balita dan orang tua atau wali balita megundurkan diri dari penelitian, serta balita mengkonsumsi obat cacing kurang dari 6 bulan terakhir. 
Variabel terikat pada penelitian ini yaitu infeksi kecacingan berdasarkan tanda dan gejala. Tanda dari infeksi cacing tidak bergantung pada persepsi, tetapi lebih ke progresifitas, berupa tanda positif dan tanda negatif. Tanda infeksi cacing diperoleh dari pemeriksaan laboratorium dan pengamatan cacing pada feses. Pemeriksaan sampel feses (tinja) digunakan untuk memeriksa telur cacing STH, setiap anak yang terpilih di berikan pot feses (tinja) untuk pengambilan feses (tinja) di lakukan di rumah. Setelah sampel feses terkumpul keesokan harinya diambil dan di bawa ke Laboratorium Parasitologi Fakultas Kedokteran Universitas Diponegoro Semarang untuk diperiksa telur cacing. Identifikasi telur cacing dengan teknik Kato Katz, sampel feses diambil untuk melihat keberadaan telur cacing selain itu juga bertujuan untuk mengetahui berat ringannya infeksi cacing dalam usus yang dilakukan oleh tenaga ahli. Subjek dikatakan mengalami kecacingan apabila hasil uji laboratorium positif dan ditemukan cacing pada feses seubjek. Pemeriksaan kecacingan juga ditentukan melalui gejala infeksi kecacingan. Gejala bersifat subyektif, dan tergantung dari persepsi subjek. Wawancara dilakukan dengan konsultasi langsung kepada pakar (dokter) mengenai penyakit yang diakibatkan oleh infeksi cacing serta nilai CF (Certainty Factor) setiap gejala terhadap setiap penyakit yang dijadikan bahan penelitian. Skor mual $(0,4)$, muntah $(0,4)$, berat badan turun $(0,4)$, dan nafsu makan berkurang $(0,8)$. Subjek dinyatakan positif apabila skor gejala $>95 \%$, dengan perhitungan $\frac{\text { jumlah } C F}{2} \times 100 \% \cdot .^{21}$

Variabel bebas yaitu asupan protein,zat besi, dan seng diperoleh dari wawancara Semi Quantitative Food Frequency Questionnaire (SQFFQ) kepada ibu atau pengasuh. Hasil SQFFQ selanjutnya dianalisis dengan Nutrisurvey 2007 dan dibandingan dengan AKG untuk mengetahui persentase asupan seng dan zat besi yang dikonsumsi subjek. Asupan subjek dibagi menjadi 2 kategori yaitu asupan cukup dan kurang, dengan kriteria kategori pemenuhan asupan berdasarkan kategori kecukupan gizi yaitu asupan kurang $(<90 \%)$ dan asupan cukup (>90\%). ${ }^{12}$

Variabel perancu dalam penelitian ini adalah data tentang personal hygiene dan sanitasi lingkungan yang diambil dengan menggunakan wawancara kuisioner dan pengamatan. Kuesioner personal hygiene digunakan untuk melihat hubungan kebersihan perorangan dengan infeksi kecacingan. Hasil pengisian kuesioner kemudian diberikan skor sesuai dengan perolehan nilai. Penilaian kuisioner personal hygiene tidak baik jika jawaban benar $\leq 70$ $\%$ ( nilai 0 ) dan baik jika jawaban benar $>70 \%$ (nilai 1). Kuesioner sanitasi lingkungan digunakan untuk menilai status kesehatan suatu lingkungan. Hasil pengisian kuesioner kemudian dinilai sesuai dengan Keputusan Menteri Kesehatan RI Nomor 829/Menkes/SK/VII/1999 dan akan dilakukan koding. Kode "0" apabila sanitasi lingkungan tidak baik atau jumlah nilai <334. Kode "1" apabila sanitasi lingkungan baik atau jumlah nilai $\geq 334 .{ }^{22}$

Data yang sudah dikumpulkan kemudian diolah menggunakan program Statistical Packages for Social Sciene (SPSS) dalam melakukan analisis univariat untuk mendeskripsikan variabel. Analisis bivariat untuk mengetahui hubungan masing-masing variabel dengan variabel terikat menggunakan uji Fisher's Exact.

Tabel 1. Karakteristik Subjek

\begin{tabular}{|c|c|c|}
\hline Karakteristik Subjek & $\mathbf{n}$ & $\%$ \\
\hline \multicolumn{3}{|l|}{ Jenis Kelamin } \\
\hline Laki-laki & 20 & 40 \\
\hline Perempuan & 30 & 60 \\
\hline \multicolumn{3}{|l|}{ Usia } \\
\hline $2-3$ tahun & 25 & 50 \\
\hline $3-4$ tahun & 16 & 32 \\
\hline $4-5$ tahun & 9 & 18 \\
\hline \multicolumn{3}{|l|}{ Status Gizi BB/TB } \\
\hline Wasting $(<-2$ sd $)$ & 2 & 4 \\
\hline Normal $(-2 \mathrm{sd}-2 \mathrm{sd})$ & 47 & 94 \\
\hline Overweight (>2 sd) & 1 & 2 \\
\hline \multicolumn{3}{|l|}{ Status Gizi BB/U } \\
\hline Severe underweight $(<-3 \mathrm{sd})$ & 2 & 4 \\
\hline Undeweight $(-3 \mathrm{sd}-(-2) \mathrm{sd})$ & 8 & 16 \\
\hline Normal $(-2 \mathrm{sd}-2 \mathrm{sd})$ & 40 & 80 \\
\hline \multicolumn{3}{|l|}{ Status Gizi TB/U } \\
\hline Severe stunting $(<-3 \mathrm{sd})$ & 4 & 8 \\
\hline Stunting $(-3 \mathrm{sd}-(-2) \mathrm{sd})$ & 9 & 18 \\
\hline Normal $(-2 \mathrm{sd}-2 \mathrm{sd})$ & 37 & 74 \\
\hline \multicolumn{3}{|l|}{ Kecukupan Asupan Protein } \\
\hline Kurang $(<90 \%)$ & 25 & 50 \\
\hline Cukup $(90 \%-120 \%)$ & 19 & 38 \\
\hline Lebih $(>120 \%)$ & 6 & 12 \\
\hline \multicolumn{3}{|l|}{ Kecukupan Asupan Zat Besi } \\
\hline Kurang $(<90 \%)$ & 30 & 60 \\
\hline Cukup $(90 \%-120 \%)$ & 13 & 26 \\
\hline Lebih $(>120 \%)$ & 7 & 14 \\
\hline \multicolumn{3}{|l|}{ Kecukupan Asupan Seng } \\
\hline Kurang $(<90 \%)$ & 11 & 22 \\
\hline Cukup $(90 \%-120 \%)$ & 19 & 38 \\
\hline Lebih $(>120 \%)$ & 20 & 40 \\
\hline
\end{tabular}

\section{HASIL}

\section{Karakteristik Subjek}

Tabel 1 Total subjek yang terlibat sampai akhir penelitian sejumlah 50 anak. Subjek penelitian sebagian besar berjenis kelamin perempuan, yaitu 30 orang $(60 \%)$. Hasil dari pengukuran antropometri didapatkan $4 \%$ subjek mengalami wasting. $16 \%$ subjek mengalami underweight dan $2 \%$ subjek mengalami severe underweight. Kemudian 18\% subjek mengalami stunting dan $8 \%$ subjek mengalami 
severe stunting. Pada penelitian ini ditemukan bahwa $50 \%$ subjek kekurangan asupan protein, 60\% subjek kekurangan asupan zat besi. Berbeda dengan asupan protein dan zat besi, sebagian besar subjek memiliki asupan seng yang berlebih yaitu $40 \%$.

Tabel 2 menunjukan hasil infeksi kecacingan pada balita. Gjala yang paling banyak dialami oleh subjek adalah nafsu makan berkurang yang dialami oleh $33(66 \%)$ subjek, dan berat badan turun sebanyak $24(48 \%)$ subjek. Berdasarkan gejala terdapat $6 \%$ subjek positif. Berdasarkan tanda terdapat $2 \%$ subjek yang positif infeksi kecacingan. Namun, hasil uji laboratorium sampel feses semua subjek dengan metode kato katz dinyatakan negatif.

Tabel 2. Data Tanda dan Gejala Infeksi Kecacingan

\begin{tabular}{lcc}
\hline \multicolumn{1}{c}{ Variabel Kecacingan } & N & Persentase (\%) \\
\hline Gejala Infeksi Kecacingan & & \\
Mual & & \\
$\quad$ Ya & 15 & 30 \\
$\quad$ Tidak & 35 & 70 \\
Muntah & 15 & 30 \\
$\quad$ Ya & 35 & 70 \\
$\quad$ Tidak & & \\
Nasfu makan berkurang & 33 & 66 \\
$\quad$ Ya & 67 & 34 \\
$\quad$ Tidak & & \\
Berat badan turun & 24 & 48 \\
$\quad$ Ya & 26 & 52 \\
$\quad$ Tidak & & \\
Tanda Infeksi Kecacingan & & \\
Terdapat Cacing pada Feses & & 2 \\
$\quad$ Ya & 1 & 98 \\
$\quad$ Tidak & 49 & \\
Uji laboratorium & & 0 \\
$\quad$ Positif & 0 & 100 \\
$\quad$ Negatf & 50 & \\
\hline
\end{tabular}

Tabel 3. Skor Tanda dan Gejala Infeksi Kecacingan

\begin{tabular}{ccc}
\hline \multicolumn{1}{c}{ Variabel } & n & Persentase (\%) \\
\hline Tanda Infeksi Cacing & & \\
Positif & 1 & 2 \\
Negatif & 49 & 98 \\
Gejala Infeksi Cacing & & \\
Positif & 3 & 6 \\
Negatif & 47 & 94 \\
\hline
\end{tabular}

\section{Infeksi Kecacingan Pada Balita}

Tabel 3 menunjukan hasil infeksi kecacingan pada balita berdasarkan tanda dan gejala. Tanda infeksi cacing yaitu terdapat cacing pada feses dan gatal disekitar anus dialami oleh $2 \%$ subjek. Sedangkan sebanyak 6\% subjek diketahui positif mengalami 4 gejala infeksi kecacingan.
Tabel 4. Variabel Higienitas dan Sanitasi

\begin{tabular}{|c|c|c|}
\hline $\begin{array}{c}\text { Variabel Higiene dan } \\
\text { Sanitasi } \\
\end{array}$ & $\mathbf{n}$ & Persentase $(\%)$ \\
\hline \multicolumn{3}{|l|}{ Kebiasaan Mencuci Tangan } \\
\hline \multicolumn{3}{|l|}{ Air dan Sabun } \\
\hline Ya & 31 & 62 \\
\hline Tidak & 19 & 38 \\
\hline \multicolumn{3}{|l|}{ Penggunaan sabun pribadi } \\
\hline $\mathrm{Ya}$ & 14 & 28 \\
\hline Tidak & 36 & 72 \\
\hline \multicolumn{3}{|l|}{ Setelah Bermain } \\
\hline Ya & 23 & 46 \\
\hline Tidak & 27 & 54 \\
\hline \multicolumn{3}{|l|}{ Sebelum dan Setelah Makan } \\
\hline $\mathrm{Ya}$ & 44 & 88 \\
\hline Tidak & 6 & 12 \\
\hline \multicolumn{3}{|l|}{ Setelah BAB } \\
\hline $\mathrm{Ya}$ & 46 & 92 \\
\hline Tidak & 4 & 8 \\
\hline \multicolumn{3}{|l|}{ Pemakaian Alas Kaki } \\
\hline Pakai & 32 & 64 \\
\hline Tidak Pakai & 18 & 36 \\
\hline \multicolumn{3}{|l|}{ Kebersihan Kuku } \\
\hline $\begin{array}{l}\text { Potong kuku } 1 \text { minggu } \\
\text { sekali }\end{array}$ & 26 & 52 \\
\hline Potong kuku > 1 minggu & 24 & 48 \\
\hline \multicolumn{3}{|l|}{ Kebiasaan menggigit kuku } \\
\hline $\mathrm{Ya}$ & 23 & 46 \\
\hline Tidak & 27 & 54 \\
\hline \multicolumn{3}{|l|}{ Sarana Air Bersih } \\
\hline Milik Sendiri & 26 & 52 \\
\hline Bukan Milik Sendiri & 24 & 48 \\
\hline \multicolumn{3}{|c|}{ Pembuangan Kotoran (Jamban) } \\
\hline Tertutup & 23 & 46 \\
\hline Tidak Tertutup & 27 & 54 \\
\hline \multicolumn{3}{|l|}{ Lantai Rumah } \\
\hline Kedap Air & 34 & 68 \\
\hline Tidak Kedap Air & 18 & 32 \\
\hline \multicolumn{3}{|l|}{ Personal Hiegiene } \\
\hline Baik & 27 & 54 \\
\hline Tidak Baik & 23 & 46 \\
\hline \multicolumn{3}{|l|}{ Sanitasi Lingkungan } \\
\hline Baik & 19 & 38 \\
\hline Tidak Baik & 31 & 62 \\
\hline
\end{tabular}

Tabel 4 menyajikan data tentang personal hygiene subjek balita dan sanitasi lingkungan yang ada disekitar subjek. Data personal hygiene subjek meliputi kebiasaan mencuci tangan menggunakan sabun dan air bersih, pemakaian alas kaki, dan kebersihan kuku. Sebanyak $62 \%$ subjek mencuci tangan dengan sabun dan air mengalir. Sebagian besar subjek diketahui memakai sabun batang yang digunakan untuk satu keluarga yaitu sebanyak $72 \%$. Kebiasaan cuci tangan setelah bermain tidak dilakukan oleh 54\% subjek, sebelum dan setelah makan tidak dilakukan oleh $12 \%$, dan tidak dilakukan setelah buang air besar sebanyak $8 \%$. Terdapat $36 \%$ 
subjek yang tidak memakai alas kaki ketika bermain, khususnya di tanah. Sebanyak $48 \%$ subjek tidak rutin dipotong kukunya oleh ibu subjek setiap satu minggu sekali, dan subjek yang masih sering menggigit kukunya sebanyak $46 \%$.

Selain personal hygiene, sanitasi lingkungan merupakan salah satu faktor yang mempengaruhi terjadinya infeksi kecacingan. Subjek yang tidak memiliki sumber air bersih yang memenuhi syarat dan milik sendiri sebanyak $48 \%$. Subjek yang memiliki jamban tidak tertutup sebanyak 54\% subjek. Jenis lantai rumah tidak kedap air dimiliki oleh $32 \%$ subjek. Tabel 3 menunjukkan data hasil pengamatan dan wawancara mengenai sanitasi lingkungan dan personal hygiene. Hasil wawancara disajikan dalam bentuk skor untuk menentukan gambaran baik atau tidaknya personal higiene dan sanitasi lingkungan. Sebanyak $38 \%$ orang tua subjek mempunyai sanitasi lingkungan yang baik dan sebanyak $54 \%$ orang tua subjek mempunyai personal hygiene yang baik

\section{PEMBAHASAN}

Subjek pada penelitian ini yaitu balita berusia 2 - 5 tahun. Balita biasanya lebih mudah terserang penyakit infeksi, karena sistem pertahanan tubuh balita terhadap infeksi masih dalam tahap perkembangan. ${ }^{23}$ Infeksi merupakan salah satu penyakit yang sering terjadi pada anak balita. Pada usia ini anak sudah mulai beraktivitas seperti memasukkan jari ditangan, bermain ditanah dan lainlain. Infeksi kecacingan berdampak buruk terhadap perkembangan kesehatan dan mental bahkan dapat menghambat tumbuh kembang anak, kecacatan dan kebutaan. ${ }^{24}$

Dalam penelitian ini diketahui subjek yang memiliki status gizi wasting adalah $4 \%$, subjek yang memiliki status gizi stunting adalah $26 \%$ dan yang memiliki status gizi underweight adalah $20 \%$. Hubungan infeksi dengan status gizi sangat erat, demikian juga sebaliknya. Penyakit infeksi dengan status gizi kurang merupakan hubungan timbal balik. ${ }^{25}$ Artinya penyakit infeksi dapat memperburuk keadaan gizi dan keadaan gizi yang buruk dapat mempermudah anak terkena infeksi. ${ }^{26}$

Anak yang memiliki status gizi kurang/buruk biasanya mengalami defisiensi zat gizi penting, sehingga rentan terhadap infeksi. Jumlah subjek yang temasuk kategori kurang asupan protein sebanyak $50 \%$, kurang asupan zat besi sebanyak $60 \%$, dan asupan seng lebih sebanyak $40 \%$. Sebagian besar subjek memiliki pola makan yang sama yaitu memakan nasi hanya dengan kuah sayur, karena subjek sudah mulai memilih makanan kesukaan mereka sendiri. Makanan sumber energi utama yang diasup subjek adalah nasi. Subjek mengasup tempe dan tahu 2-3 kali seminggu sebagai sumber protein nabati. Protein hewani yang paling sering diasup adalah telur, subjek juga biasa mengonsumsi ikan 23 kali seminggu, sedangkan untuk daging ayam dan daging merah hanya dikonsumsi sekitar 1-2 sebulan. Selain itu, subjek juga banyak yang mengasup susu kemasan $>4$ kali sehari dan snack roti 2 kali seminggu sebagai makanan selingan. Asupan seng yang berlebih terjadi karena sebagian besar subjek masih mengonsumsi susu $>4$ kali sehari terutama susu kemasan yang mengandung seng lebih banyak dibanding zat besi. Selain itu kebutuhan seng untuk balita relative lebih kecil dibanding kebutuhan zat besi dan protein menurut AKG.

Data yang diambil untuk mengkaji subjek yang terkena infeksi kecacingan menggunakan pengamatan serta wawancara terkait tanda dan gejala infeksi kecacingan. Wawancara dilakukan dengan konsultasi langsung kepada pakar (dokter) mengenai penyakit-penyakit infeksi tropis yang diakibatkan oleh infeksi cacing serta nilai CF (certainty factor) setiap gejala terhadap setiap penyakit yang dijadikan bahan penelitian. ${ }^{21}$ Subjek yang mendapatkan skor gejala $>95 \%$ dinyatakan positif. Berdasarkan gejala, diketahui sebanyak $6 \%$ subjek diketahui positif infeksi kecacingan Subjek yang positif diketahui memiliki gejala nafsu makan berkurang, berat badan menurun, mual, dan muntah. ${ }^{27}$ Berdasarkan tanda, $2 \%$ subjek diketahui positif infeksi kecacingan karena terdapat cacing pada feses dan gatal disekitar anus. Subjek positif di sebabkan oleh cacing kremi (Enterobius Vermicularis). Cacing kremi ini selain menimbulkan gejala gangguan pada saluran cerna, dan menyebabkan gatal di sekitar anus (pruritus ani) yang diakibatkan oleh cacing dewasa yang bertelur di sekitar daerah perianal. Berkurangnya nafsu makan sehingga menyebabkan berat badan anak menurun dan akan mempengaruhi status gizi anak, bahkan jika terjadi infeksi berat bisa menimbulkan malabsorpsi makanan. ${ }^{28,29}$ Pemindahan telur cacing E.Vermicularis pada manusia dapat terjadi melalui auto infeksi, karena daerah perianal gatal, digaruk, telur menempel pada tangan atau bawah kuku, kemudian telur ini termakan oleh hospes yang sama.

Uji laboratorium dilakukan sebagai uji penunjang untuk mengidentifikasi tanda infeksi kecacingan. Uji ini dilakukan untuk mengetahui telur cacing secara kuantitatif dengan menggunakan metode Kato-Katz. Pemeriksaan ini bertujuan untuk menegakkan diagnosis pasti, ada dan tidaknya infeksi cacing, berat ringannya infeksi serta jenis telur cacing yang ada ${ }^{30}$ Data hasil pemeriksaaan laboratorium infeksi kecacingan menunjukkan bahwa semua subjek penelitian $100 \%$ tidak terinfeksi kecacingan. Sensitivitas dan spesifisitas metode katokatz berbeda untuk setiap cacing, untuk A. Lumbricoides (96,9\%, 96,1\%), Hookworm $(65,2 \%, 93,8 \%)$ dan T. Trichiura 
$(91,4 \%, 94,4 \%)$, yang berarti semakin tinggi sensitivitas suatu tes, maka semakin besar pula kemungkinan mendeteksi kecacingan pada subjek. Semakin tinggi spesifisitas suatu tes, maka semakin besar kemungkinan subjek negatif dalam pemeriksaan yang tidak dimasukkan dalam kelompok yang menderita kecacingan. Cacing yang ditemukan dalam penelitian ini adalah jenis cacing kremi, namun sensitivitas dan spesifitas untuk cacing jenis ini sendiri tidak ditemukan. Pada pemeriksaan KatoKatz yang dilakukan satu kali memiliki kapasitas deteksi yang secara signifikan lebih rendah daripada metode FEC (formol eter concentration) dalam mendiagnosis cacing. Pada uji Kato-Katz, materi sampel yang digunakan jumlahnya sedikit, kemungkinan untuk mendeteksi infeksi cacing, diperkirakan lebih rendah. ${ }^{31}$ Telur cacing E.vermicularis jarang di temukan dalam feses, hanya $5 \%$ yang positif pada orang - orang yang menderita infeksi ini. Pada pemeriksaan tinja dapat di temukan adanya cacing dewasa. Cacing jantan dewasa setelah kopulasi mati dan keluar bersama tinja. Sementara dengan metode "Scotch adhesive tape swab", dapat menemukan telur yang di letakkan di daerah perianal.

Penelitian ini menunjukkan masih ada subjek dengan personal hygiene yang kurang. Hal ini dapat diketahui dari kebiasaan cuci tangan subjek yang masih kurang yaitu tidak mencuci tangan dengan air dan sabun sebanyak 38\%, tidak cuci tangan setelah bermain $54 \%$, tidak cuci tangan setelah dan sebelum makan 12\%,dan tidak cuci setelah BAB $8 \%$. Sebanyak $54 \%$ subjek diketahui mempunyai kebiasaan menggigit kuku. Infeksi cacing kremi terjadi akibat tertelannya telur yang infektif atau akibat kontak tangan/kuku dengan kulit di sekitar anal, udara/inhalasi debu yang mengandung telur, baju tidur dan pakaian dalam. Berdasarkan teori, kebiasaan mencuci tangan dan kebersihan kuku memiliki peran penting dalam terjadinya infeksi cacing. ${ }^{32}$ Kebiasaan menggigit kuku dan cuci tangan adalah faktor yang berisiko terhadap penularan telur cacing, terutama cacing kremi karena telur cacing kremi bersifat lengket dan dapat menempel di bawah kuku anak. Beberapa subjek diketahui masih tidak memakai alas kaki ketika bermain, khususnya di tanah. Berdasarkan teori, tanah merupakan media mutlak yang diperlukan oleh beberapa jenis cacing untuk dapat masuk ke pori-pori kulit,sehingga penggunaan alas kaki diperlukan untuk megurangi kontak dengan tanah.

Pemindahan telur cacing E.Vermicularis pada manusia dapat terjadi melalui autoinfeksi, kontak langsung, pernapasan dan terjadi retrofeksi. Hal ini tidak sesuai dengan teori, dari hasil penelitian didapatkan kenyataan bahwa subjek yang terinfeksi cacing E. Vermicularis memiliki perilaku personal hygiene yang baik dan subjek yang tidak terinfeksi tetapi memiliki perilaku personal hygiene yang kurang baik. Kebiasaan personal hygiene yang kurang baik mungkin dikarenakan sarana yang ada kurang mencukupi, keluarga kurang memberi dukungan untuk mebiasakan anaknya menggunakan alas kaki ketika bermain diluar rumah, mencuci tangan sebelum dan sesudah makan, memotong kuku seminggu sekali dan mereka tidak mengetahui pentingnya menjaga kesehatan diri sendiri. Hasil personal hygiene pada penelitian ini tidak sejalan dengan penelitian sebelumnya. Pada penelitian Tahun 2008 menemukan adanya hubungan yang bermakna antara kebiasaan mencuci tangan dengan infeksi cacing usus dan didapatkan prevalensi yang cukup tinggi pada anak yang sering menggigit kuku ketika sedang bermain dan memasukkan jari tangan kedalam mulut dan beberapa faktor sanitasi lingkungan yang buruk. Penelitian ini sejalan dengan yang dilakukan pada Tahun 2008 di Kec. Sibolga. ${ }^{33}$ Tahun 2010 di Kel. Karangroto Semarang dan tahun 2013 di Kab. Kep. Talaud bahwa tidak ada hubungan yang bermakna antara penggunaan alas kaki dengan infeksi cacing usus. ${ }^{7,34}$

Data sanitasi lingkungan diperoleh melalui pengamatan dan wawancara. Sanitasi lingkungan subjek seperti sarana air dan lantai rumah,sebagian besar sudah baik dan memenuhi syarat. ${ }^{28}$ Mengingat bahwa Enterobiasis atau penyakit infeksi cacing kremi adalah masalah kesehatan keluarga maka lingkungan hidup keluarga harus diperhatikan. Sebanyak 57\% subjek diketahui masih menggunakan jamban yang tidak tertutup. Hal ini terjadi karena warga masih menggemari WC jongkok, menurut penuturan responden mereka terbiasa buang air besar dengan posisi jongkok sehingga tidak nyaman dengan menggunakan WC leher angsa. ${ }^{32}$ Menggunakan jamban yang tidak sehat dapat meningkatkan risiko tercemarnya jamban oleh feses maupun kotoran lain. Feses manusia mengandung organisme pathogen seperti bakteri Salmonella sp, Amoeba sp, virus, hingga telur cacing. Apabila seseorang melakukan praktik $B A B$ di jamban yang tidak sehat, kemudian kontak dengan feses yang terkontaminasi telur cacing, kemudian telur cacing akan masuk ke dalam tubuh manusia dan berkembang hingga menjadi cacing dewasa. Subjek dalam penelitian ini yang tidak memiliki jamban tertutup tidak terinfeksi cacing usus hal ini terjadi karena anak yang tidak memiliki jamban sebagian besar memiliki higiene personal dan sanitasi lingkungan dengan baik dan benar. Dalam penelitian ini tidak ada hubungan antara kepemilikkan jamban dengan infestai cacing, ini dimungkinkan karena sebagian besar responden mempunyai jamban sendiri dengan saluran pembuangan untuk BAB dan anak dibiasakan untuk 
tidak $\mathrm{BAB}$ dilingkungan sekitar rumah, sehingga penyebaran penyakit melalui tinja dapat dicegah.

Subjek dengan asupan protein, zat besi, dan seng kurang, tidak mengalami infeksi kecacingan. Dalam penelitian ini diketahui bahwa asupan protein,zat besi,dan seng tidak memiliki hubungan dengan infeksi kecacingan,hal ini dapat diartikan bahwa asupan tersebut tidak menjadi faktor yang mempengaruhi infeksi kecacingan. Tidak adanya hubungan antara asupan gizi dengan kejadian infeksi kecacingan dapat terjadi karena dipengaruhi oleh faktor usia, karena semakin bertambahnya usia anak maka tingat infeksi semakin menurun. Asupan seng subjek yang cukup menjadi salah satu faktor yang dapat meningkatkan system imunitas tubuh. Faktor lainnya adalah meningkatnya perilaku hidup bersih dan sehat (PHBS) hal ini dapat dilihat dari pengetahuan personal hygiene dan sanitasi lingkungan subjek yang baik. Kondisi alam atau lingkungan geografi juga mempengaruhi angka kejadian kecacingan. Pengambilan data penelitian ini dilakukan pada musim kemarau (bulan Juli Agustus) sehingga angka kejadian infeksi kecacingan pada penelitian ini sangat rendah. ${ }^{35} \mathrm{Hal}$ ini sejalan dengan hasil penelitian yang dilakukan di Kota Palembang di musim kemarau pada subjek anak memiliki angka kejadian infeksi kecacingan yang rendah (hanya 6,8\%). Musim kemarau, udara dan kondisi tanah kering tidak sesuai untuk perkembangan cacing. ${ }^{2}$ Pada subjek dengan infeksi cacing E. Vermicularis, tempat tidur dibersihkan karena mudah sekali tercemar oleh telur cacing infektif. Diusahakan sinar matahari bisa langsung masuk ke kamar tidur, sehingga dengan udara yang panas pada saat kemarau serta ventilasi yang baik pertumbuhan telur akan terhambat karena telur rusak pada temperatur lebih tinggi dari $46^{\circ} \mathrm{C}$ dalam waktu 6 jam. Karena infeksi Enterobius mudah menular dan merupak penyakit keluarga maka tidak hanya penderitanya saja yang diobati tetapi juga seluruh anggota keluarganya secara bersama-sama. Ketika mendapatkan prevalensi yang sangat rendah, penelitian lainnya menyarankan diperlukan menggunakan metode PCR (polymerase chain reaction) untuk mendiagnosis karena metode yang menggunakan mikroskop kurang sentitif. ${ }^{36}$

\section{SIMPULAN}

Tidak ditemukan hubungan antara personal hygiene dan sanitasi lingkungan dengan kejadian infeksi cacing. Tidak ditemukan hubungan antara asupan protein, zat besi dan seng dengan kejadian infeksi cacing E. Meskipun demikian berdasarkan tanda dan gejala infeksi kecacingan ditemukan satu subjek yang positif infeksi kecacingan.

\section{SARAN}

Penelitian terhadap infeksi kecacingan untuk mendapatkan hasil yang lebih sensitif sebaiknya menggunakan metode PCR karena dua kali lebih sensitif dalam mendeteksi adanya telur cacing dibandingkan dengan metode Kato-Katz. Sebaiknya setiap 6 bulan sekali anak perlu diberikan obat cacing untuk mencegah infeksi kecacingan

\section{UCAPAN TERIMA KASIH}

Puji syukur penulis panjatkan kepada Allah SWT atas limpahan rahmat-Nya. Ucapan terima kasih kepada subjek penelitian di Kelurahan Jomblang, Semarang atas kesediaannya menjadi subjek penelitian dan membantu kelancaran terlaksananya penelitian ini. Penulis juga mengucapkan terima kasih untuk semua pihak yang mendukung terlaksananya penelitian ini.

\section{DAFTAR PUSTAKA}

1. Welasasih B,Wirjatmadi R. Beberapa Faktor Yang Berhubungan Dengan Status Gizi Balita Stunting. Indones J Public Heal. 2012;3:8.

2. Pratiwi, R.H., Suyatno, Aruben R. Faktor Faktor Yang Berhubungan Dengan Berat Kurang (Underweight) Pada Balita Di Perkotaan Dan Perdesaan Indonesia Berdasarkan Data Riskesdas Tahun 2013. J Kesehat Masy. 2015;3(2):2356-3346.

3. Ningsih I, Nur Isnaeni $F$, Rahmawati $T$. Hubungan Kesehatan Lingkungan Terhadap Status Gizi Anak Prasekolah Di Kelurahan Semanggi Dan Sangkrah Kecamatan Pasar Kliwon Surakarta. Universitas Muhammadiyah Surakarta 4; 2013.

4. Sanchez A, Gabrie J, Usuanlele MT, Rueda M, Canales M, Gyorkos T. Soil-Transmitted Helminth Infections And Nutritional Status In School-Age Children From Rural Communities In Honduras. Plos Negl Trop Dis. 2013;7(8):E2378. Available From: Http://Dx.Plos.Org

5. Kattula D, Sarkar R, Rao Ajjampur S, Minz S, Levecke B, Muliyil J, Et Al. Prevalence \& Risk Factors For Soil Transmitted Helminth Infection Among School Children In South India. Indian J Med Res. 2014;139(1):76-82.

6. Crompton D, Nesheim M, Al-Adhroey A, Ithoi I, Abdulsalam A, Surin J, Et Al. Nutritional Impacts Of Intestinal Helminthiasis During The Human Life Cycle. Annu Rev Nutr [Internet]. 2012;22(1):35-59. Available From: Http://Www.Annualreviews.Org/Doi/10.1146/ Annurev.Nutr.22.120501.13453

7. Endriani, Mifbakhudin, Sayono. Beberapa Faktor Yang Berhubungan Dengan Kejadian 
Kecacingan Pada Anak Usia 1-4 Tahun. J Kesehat Masy Indones .2011;7:22-35. Available From:

Http://Download.Portalgaruda.Org/Article

8. Soedarto. Parasitologi Klinik.Surabaya:Airlangga University Press; 2008.71-91.

9. Nacher M, Singhasivanon Pprata, Yimsamran S, Manibunyong W, Thanyavanich N, Wuthisen P, Et Al. Intestinal Helminth Infections Are Associated With Increased Incidence Of Plasmodium Falciparum Malaria In Thailand. Am J Trop Med Hyg. 2006;22(1):107-13. Available

From:

Http://Www.Malariajournal.Com/

10. Sunita A. Penuntun Diet. Jakarta: Pt Gramedia Pustaka Utama; 2007.

11. Yap P, Utzinger J, Hattendorf J, Steinmann P. Influence Of Nutrition On Infection And ReInfection With Soil-Transmitted Helminths: A Systematic Review. Parasites And Vectors. 2014;7(1):1-14.

12. Gibson Rs. Zinc: The Missing Link In Combating Micronutrient Malnutrition In Developing Countries. Proc Nutr Soc [Internet]. 2006;65(1):51-60. Available From: Http://Www.Journals.Cambridge.Org/Abstract S0029665106000073

13. Wessels I, Maywald M, Rink L. Zinc As A Gatekeeper Of Immune Function. Nutrients. 2017;9(12):9-12.

14. Cherayil B. The Role Of Iron In The Immune Response To Bacterial Infection. Immunol Res. 2011;50(1):1-9.

15. Jatmiko S. Peran Basofil Dalam Imunitas Terhadap Cacing. Biomedika. 2012;4(1).

16. Balitbangkes. Laporan Nasional Riset Kesehatan Dasar. Jakarta; 2009.

17. Hidayati L, Hadi H, Kumara A. Kekurangan Energi Dan Zat Gizi Merupakan Faktor Risiko Kejadian Stunted Pada Anak Usia 1-3 Tahun Yang Tinggal Di Wilayah Kumuh Perkotaan Surakarta. J Kesehat. 2010;89-104.

18. Arnisam, Salfiyadi T, Simehate L. Hubungan Asupan Mineral Zinc (Seng) Dan Vitamin A Dengan Kejadian Diare Pada Balita Di Kecamatan Seulimeum. Idea Nurs J. 2013;4(3).

19. Ardiaria M, Nuryanto. Hubungan Status Gizi Dan Asupan Besi Dan Seng Terhadap Fungsi Motorik Anak Usia 2-5 Tahun. J Nutr Heal. 2014;

20. Candra A, Ratna E, Ardiaria M, Probosari E. Pengaruh Suplementasi Seng Dan Zat Besi Terhadap Nafsu Makan, Status Gizi, Dan Kecerdasan Intelektual (Intelligence Quotient) Balita. Universitas Diponegoro; 2016.
21. Aprilliani Pf. Implementasi Certainty Factor Pada Diagnosa Penyakit Infeksi Tropis. J Ris Sains Dan Teknol. 2017;1.

22. Kementrian Kesehatan Republik Indonesia. Tentang Persyaratan Kesehatan Perumahan,. Keputusan Menteri Kesehat. 1999;(No. 829/Menkes/Sk/Vii).

23. Jafar N. Pertumbuhan Balita. Universitas Hasanuddin; 2016.

24. Yudhastuti R, M. Farid Dl. Kebersihan Diri Dan Sanitasi Rumah Pada Anak Balita Dengan Kecacingan. Kesehat Masy Nasiona. 2012;6(4).

25. Dewi R, Zulaekah S. Hubungan Asupan Energi, Protein, Besi, Seng Dengan Status Imunitas Anak Balita Di Perkampungan Kumuh Kota Surakarta. 2010;129-39.

26. Maya Sp. Hubungan Antara Riwayat Penyakit Infeksi Dengan Status Gizi Pada Anak Batita Di Desa Mopusi Kecamatan Lolayan Kabupaten Bolaang Mongondow. Sam Ratulangi Manado; 2015.

27. Inge S, Sumariah I, Pudji Ks, Saleha S. Buku Ajar Parasitologi Kedokteran. 4th Ed. Jakarta: Balai Penerbit Fkui; 2008.

28. Yulianto E. Hubungan Higiene Sanitasi Dengan Kejadian Penyakit Cacingan Pada Siswa Sekolah Dasar Negeri Rowosari 01 Kecamatan Tembalang Kota Semarang. Ilmu Keolahragaan; 2008.

29. Rahmi N. Hubungan Asupan Zat Besi (Fe) Dan Infeksi Kecacingan Terhadap Kejadian Anemia Pada Anak Jalanan Di Kecamatan Mariso Kota Makassar. Uin Alauddin Makassar; 2014.

30. Nurul S. Uji Diagnostik Kecacingan Antara Pemeriksaan Feses Dan Pemeriksaan Kotoran Kuku Pada Siswa Sdn 1 Krawangsari Kecamatan Natar Lampung Selatan. Universitas Lampung; 2016.

31. Set P.H. Comparative Study Of Saline Wet Mount And Modified Kato-Katz Methods For Detection Of Intestinal Helminths From Under 5 Year Children Of Day Care Centres, Mingaladon Township. Myanmar Heal Sci Res. 2017;29(1).

32. Andaruni A. Gambaran Faktor-Faktor Penyebab Infeksi Cacingan Pada Anak Di Sdn 01 Pasirlangu Cisarua. Students E-Journal [Internet]. 2012;1:28. Available From: Http://Jurnal.Unpad.Ac.Id/Ejournal/Article/Vie w/597

33. Rahmad R. Hubungan Higiene Perorangan Siswa Dengan Infeksi Kecacingan Anak Sd Negeri Di Kecamatan Sibolga Kota Sibolga. Universitas Sumatera Utara; 2008.

34. Nusa L, Jootje M, Umboh, Victor D. Hubungan Antara Higiene Perorangan Dengan Infestasi Cacing Usus Pada Siswa Sd Yayasan Pendidikan 
Imanuel Akas Kec. Damau Kab. Kepulauan Talaud. Universitas Sam Ratulangi; 2013.

35. Pratikno N, Handayani W. Pengaruh Genangan Banjir Rob Terhadap Dinamika Sosial Ekonomi Masyarakat Kelurahan Bandarharjo Semarang. J
Tek Pwk. 2014;

36. World Health Organization. Helminth Control In School-Age Children. A Guide For Managers Of Control Programmes. 2011;2. 